15. Shevchenko, O., Ushchyna, Yu. (2008). Komunikatyvni kanaly formuvannia pozytyvnoho mizhnarodnoho brendu krainy (na prykladi Velykoi Brytanii). Aktualni problemy mizhnarodnykh vidnosyn: Zbirnyk naukovykh prats, vyp. 78, ch. II (u dvokh chastynakh). Kyiv: Kyivskyi natsionalnyi universytet imeni Tarasa Shevchenka Instytut mizhnarodnykh vidnosyn, 97-103.

16. British Council. URL: https://www.britishcouncil.org/

17. British Council. Culture Bridges. URL: https://www.britishcouncil.org.ua/programmes/arts/culture-bridges

18. Culture brigdes. URL: http://culturebridges.eu/team_story

19. House of Europe. URL: https://houseofeurope.org.ua/

УДК 327.3: 329.1

Марина Якимчук,

аспірантка кафедри політології та національної безпеки, Національний університет «Острозька академія», ORCID ID: 0000-0002-1089-9019

maryna.yakymchuk@oa.edu.ua

DOI 10.29038/2524-2679-2020-02-258-275

\title{
ВПЛИВ ЄВРОСКЕПТИЦИЗМУ НА ФУНКЦІОНУВАННЯ ІНСТИТУЦЙ ЄС
}

У иій статті визначено та проаналізовано ознаки євроскептицизму в інституиіях ЄС. Зокрема, охарактеризовано елементи опозицї до ЄС у Свропейській раді, Свропейській комісї, Свропейському парламенті та Раді Європейського Союзу, а також в інших допоміжних органах ЄС. Значну увагу приділено вивченню політичних поглядів Глав держав й урядів, які входять до Свропейської ради. Дослідження показало, щзо, попри членство в проєвропейських партіях, лідери, переважно держав Центрально-східної Свропи, мають зв'язки з Росією та критикують політику організації, щуо послаблюе інтеграцію. Також у статті проаналізовано ідеологію політичних партій і груп, які входять до Свропарламенту. Зауважимо, ш⿻о кількість євроскептиків у Свропарламенті не змінилася, проте між ними не спостерігаємо посилення комунікації та співробітництва. Це свідчить про зниження рівня євроскептицизму в парламенті. Крім того, охарактеризували політичні погляди комісарів і їх прихильність до ідей євроскептищизму та визначили, щзо Свропейська комісія залишається найбільш проєвропейською інституцією ЄС. У статті також розглянули євроскептицчизм 
у Раді СС. Проаналізувавии рівень опозичії до СС в урядах держав-членів, визначили, щуо сумніви щуодо політики ЄС, які спостерігаються в урядах держав-членів, уповільнюють співпрацюю. Однак складно стверджувати про негативний вплив євроскептицизму на посилення співробітництва, а тим більше простежити зростання опозииії в інституціях СС. На прояви євроскетицизму в європейських інституціях впливають також економічна ситуація, адаптованість законодавства та ситуація на міжнародній арені. У зв'язку з цзим євроскептициизм в інституціях потрібно розглядати не як загрозу європейській інтегращії, а лише як фактор уповільнення співпраці, щзо сприяє адаптації держав до нових вимог організащії.

Ключові слова: євроскептицизм; Свропейська Рада; Свропейський парламент; Свропейська комісія; Рада СС.

\section{1. ВСТУП}

Постановка проблеми. Після прийняття Лісабонського договору ЄC із міжнародної організації перетворюється в унікальне інтеграційне утворення з ознаками федерації й функціонує в новому для системи міжнародних відносин форматі [1]. Свропейський Союз став своєрідним прикладом створення та становлення інституту держави без військової сили. Більше того, за десятиліття організація не лише розширила свою територію, а й укріпила свої позиції на міжнародній арені. Безпрецедентним явищем є те, що державні органи влади розділяють повноваження 3 інституціями $\mathrm{EC}$, тобто одночасно управляють політикою держави й політикою організації, що ускладнює процес прийняття рішення [2]. Попри такі успішні результати та досягнення, ЄC зіткнувся 3 низкою перешкод і проблем, які спільними зусиллями частково вдавалося врегульовувати, що сприяло посиленню інтеграції. Розпочавши співпрацю на противагу спільним загрозам і продовжуючи кооперацію, яка грунтується на спільних інтересах та вигодах, ЄС постав перед вибором «Чи варто продовжувати інтеграцію, яка видозмінить розуміння й трактування національного суверенітету та незалежності?» У зв’язку з цим проблема євроскептицизму була лише питанням часу. Безумовно, низка зовнішніх викликів та внутрішніх криз сприяли зростанню критики до роботи інституцій. Опозиція в органах $\mathrm{CC} \mathrm{не}$ настільки висока, як у національних урядах, проте до складу інституцій входять представники з держав-членів, які через СС упроваджують та реалізують свої ідеї. Проте якщо поглянути на європейський проєкт глобально, розуміємо, що євроскептицизм - це екзистенціальне 
питання, яке рано чи пізно повинно було ввійти в порядок денний роботи Європейського Союзу та його інституцій.

Аналіз останніх досліджень і публікацій. Тривалий час опозиція в інституціях була непомітною, проте за останні декілька років цей рівень суттєво зріс. Ураховуючи новизну цієї проблеми та тенденцію зростання опозиції до ЄС, учені почали зосереджувати увагу на дослідженні євроскептицизму в інституціях організації. Опосередковано увагу на роль і значення євроскептицизму в інституціях СС звернула С. Лєконте [3]. Також вона врахувала вплив поширення євроскептицизму на неурядових акторів - ЗМІ та громадянське суспільство. Не оминув питання проявів євроскептицизму в інституціях СС один із перших теоретиків цього феномену К. Мюде [4]. Проте науковці більш детально вивчали прояви євроскептицизму в Європарламенті крізь призму партійного євроскептицизму. Але малодослідженими залишаються питання впливу опозиції $\mathrm{CC}$ на роботу інших органів організації. Саме цю проблему ми намагатимемося розв'язати в цій статті.

Мета роботи - визначити ступінь впливу євроскептицизму на інституції СС та рішення, які вони приймають.

\section{2. МЕТОДИКА ДОСЛІДЖЕННЯ}

Євроскептицизм як поняття та явище перебуває на етапі інституалізації й формування. Тому щоб дослідити вплив євроскептицизму на роботу європейських інституцій, передусім потрібно подати його трактування. Під євроскептицизмом розуміємо опозицію до діяльності ЄС, яка характеризується зниженням довіри до організації, призупиненням інтеграційних процесів і посиленням впливу Росії на держави-члени ЄС. Свроскептицизм в органах ЄС розглянемо, використовуючи метод індукції. Тобто детально проаналізуємо прояви опозиції до ЄС у кожній інституції окремо. Визначаючи рівень впливу євроскептицизму на роботу Європейської ради, Європейської комісії, Європейського парламенту та Ради ЄС, застосуємо метод синтезу й аналізу. У діяльності інституцій виявимо причини зниження довіри до організації, послаблення інтеграційних процесів та зв'язки між співробітниками інститутів і різними групами впливу, у тому числі й російськими. Також, паралельно обробляючи програми політичних партії та риторику політичних лідерів на приналежність до євроскептичних ідей, використаємо елементи контент-аналізу. Аналізуючи рівень євроскептицизму в Європейському парламенті, застосуємо статис- 
тичний метод. Крім того, скористаємося компаративним методом для порівняння даних щодо рівня євроскептицизму в європарламенті цього й попередніх скликань. Загально дослідження грунтується на структурнофункціональному підході.

\section{3. РЕЗУЛЬТАТИ ДОСЛІДЖЕННЯ}

Опозиція до ЄС в інституціях може проявлятися на кількох рівнях. Досить часто саме погляди та дії співробітників інституцій стають причинами зростання недовіри до ЄС. Також євроскептицизм може проявлятись у процесі прийняття рішень відповідно до функції інституцій, коли працівники інституцій блокують прийняття того чи іншого рішення через небажання поглиблювати співробітництво, яке може бути не проявом євроскептицизму, а справді суперечити національним інтересам державам-членам. Проте ці прояви опозиції до СС не наскільки відкриті, як у державах-членах, і прослідкувати їх досить складно через бюрократизм та багатоетапність законодавчого процесу. Свроскептицизм в органах СС може виникати через дефіцит демократії й прозорості в затвердженні того чи іншого документа. Пропри недоліки в роботі $\mathrm{CC}$, інституції все таки залишаються каркасом СС, адже саме вони ухвалюють фундаментальні рішення щодо розвитку та майбутнього $\mathrm{CC}$.

Історично склалося так, що головним політичним органом, який визначає напрямок руху організації, є Європейська рада (далі - ЄР). Хоча безпосередньо в самому процесі прийняття рішень вона участі не бере, але саме ця інституція на неформальному рівні формує порядок денний роботи ЄС. Саме Європейська рада подає кандидатури на головні посади в ЄС: голову Європарламенту та голову Єврокомісії. Політичне делегування своїх кандидатів на провідні ролі в управлінні $\mathrm{CC}$ провокує конфлікт між ЄП і ЄР. Євроскептики починають це трактувати як загрозу демократії, підриваючи довіру до організації. Саме це сталося під час обрання голови Сврокомісії У. фон де Ляєн, яка не була запропонована жодною парламентською групою СС, але яку затвердили на посаду [5]. Така політична гра свідчить, що Свропейська рада стає більш впливовою, що вказує, з одного боку, на формування політичного формату співпраці, тобто ЄС закріплює певні елементи політичної інтеграції, з іншого - на брак демократії та на те, що ЄР вибрала «зручного» кандидата для всіх [6].

До Європейської ради входять глави держав чи урядів і президент Європейської ради та президент Свропейської комісії, які не голосують. 
Також до участі залучають радників групи Антікі, перекладачів, міністрів закордонних справ. А організацією засідань та поточною роботою інституції займається кабінет президента Європейської ради Ш. Мішеля. Держави представляють глави урядів, тобто президенти чи прем'єр-міністри, із-поміж яких - 11 представників із Свропейської народної партії, сім - із проєвропейської групи «Оновлена Свропа» та шість - із «Партії європейських соціалістів», два лідери безпартійні й один із євроскептичної групи Альянс консерваторів і реформістів у Європі. В альянс євроскептиків входить прем'єр-міністр Польщі М. Моравецький [7]. Також занепокоєння викликає діяльність в інституції прем'єр міністра Болгарії Б. Борісова [8] та прем'єр-міністра Чехії А. Бабіша [9], які, хоч і входять до проєвропейських груп, проте їх приналежність до корупційних скандалів стає приводом до погіршення відносин з іншими проєвропейськими лідерами. Крім того, не варто забувати про позиції Б. Борісова й А. Бабіша щодо міграційної проблеми, котрі виступали проти прийняття мігрантів [10]. Критикувала міграційну політику СС і прем'єр-міністр Данії М. Фредеріксен [11], прем'єрміністр Австрії С. Курц [12] та прем’єр-міністр Словенії Я. Янша, партія якого фінансується організацією угорського президента В. Орбана [13]. У корупційних скандалах і зв'язках із Росією також звинувачують прем'єр-міністра Кіпру Н. Анастасіадіса, хоча його партія є однією 3 найбільш проєвропейських [14]. Окрім того, критика до ЄС лунає від прем'єр-міністра Естонії Ю. Ратаса після того, як він об'єднався в коаліцію з опозиційною євроскептичною партією [15]. Представники Італії та Литви позапартійні. Також прем’єр-міністра Італії Д. Конте можна віднести до представників м'якого євроскептицизму проте на фоні пандемії його критика СС дещо зросла [16]. На противагу такій опозиції президент Литви та прем'єр-міністри зі Швеції, Люксембургу повністю підтримують інтеграцію й виступають за конфедерацію ЄС [17]. Хоча до складу СР входять майже всі представники проєвропейських партій, ми визначили, що орієнтовно половина складу СР підтримує євроскетичні ідеї. А рівень критики до організації все-таки значний, що, безумовно, шкодить консенсусу щодо подальших етапів ведення спільної політики та зближення. Наступні декілька років ситуація суттєво не зміниться, оскільки вибори в найбільш євроскептичних урядах відбудуться через 2-3 роки.

Причиною такої політики є те, що глави урядів і держав не сприймають ЄС як єдиний орган управління та не готові брати на себе відповідальність за розв'язання проблем. Крім того, Н. Баерг 
i M. Халлерберг визначили, що політична влада та громадський євроскептицизм є причинами ослаблення позицій держав-членів у $\mathrm{Pa}-$ ді [18]. Тобто якщо суспільство та політична еліта держави проти певної політики $\mathrm{CC}$, то відповідно проти такої політики й глава держави чи уряду, що абсолютно відображає демократичний процес, проте підриває процес політичної інтеграції ЄС. Також певний дисонанс у роботу Європейської ради вносить розкол у виконавчій владі національних держав. Тобто коли президент і прем'єр-міністр виявляють бажання взяти участь у самітах $\mathrm{CP}$, проте представляють різні позиції щодо важливих напрямів співробітництва. Найбільшого розголосу набули випадки в Румунії, що траплялись у 2007 і 2012 рр., і ситуація розвивалася навіть у Конституційному Суді. Також схоже було з Польщею та Фінляндією [19]. Такі випадки засвідчують прорахунки в роботі вищого політичного органу й потребують урегулювання, щоб ЄС на міжнародній арені зміг виступати єдиною політичною силою.

Глави урядів та держав Свропейської ради хочуть зрушити з місця, проте кожен із 27 членів рухається у свій бік. Як наслідок, такі намагання рухатися вперед безрезультативні й виснажують організацію, указуючи на iіï недоліки. Та навіть якби всі члени інституції підтримували б Свропейську інтеграцію, розраховувати на посилення політичного зближення не варто. Передусім, через відсутність політичної волі глав державчленів щодо поглиблення співробітництва. Адже рушіями політичної інтеграції визначені національні представники, які відстоюють інтереси своєї держави, що не завжди відповідає інтересам ЄС. Тобто, якби вищий політичний орган був сформований не з глав держав чи урядів, а за схемою Європейської комісії чи навіть, більше того, за виборчим механізмом, як Європейський парламент, то, безумовно, результати себе не змусили б чекати. Проте виникає питання, чи не нівелюється роль державного лідера в Свропі та чи погодяться на це політичні еліти держав-членів.

Якщо Європейська рада - це політичний орган, який відповідає за стратегічний напрям розвитку організації, то формування й реалізація порядку денного роботи ЄС належить Європейській комісії (далі $€ К)$. Саме за ЄК офіційно закріплено право законодавчої ініціативи. Європейська комісія є єдиним європейських органом, де урядовці не представляють інтереси держави, а відповідають за реалізацію політики СС як організації. У зв'язку з цим інституція має одну 3 найбільш розширених структур. Зокрема, ЄК поділяється на політичну, яка нараховує 27 комісарів із кожної держави-члена по представнику, та 
адміністративну частину, котра складається з 27 генеральних директорів. Також до комісії входять помічники Свропейської комісії: консультативні комітети, наукові комітети, експертні групи та управлінські, консультативні, регуляторні комітети СК. Така розгалужена структура дає змогу політикам, урядовцям й іншим зацікавленим групам впливати на формування нормативних актів. Тому потрібно охарактеризувати та визначити ймовірний вплив євроскептичних груп та урядовців держав членів на роботу СК.

Хоча ЄК незалежна від держав-членів, певний національний фактор присутній, адже саме держава-член рекомендує свого комісарів. Усього нараховується 27 комісарів із кожної держави СС. Також треба зауважити, що кожен комісар опікується певним напрямом політики $\mathcal{C}$, тобто, попри переконання з боку $\mathrm{CC}$, що урядовці й працівники $Є К$ незаангажовані у своїх рішеннях. Комісар реалізовуватиме політику, зважаючи на досвід та переконання, які сформувалась у власній державі. Незважаючи на те, що всі сфери розвитку важливі, є стратегічні й дискусійні питання, як-от: енергетична політика, міграційна політика чи валютний союз. Тому досить важливо зробити хоча б короткий огляд політичної приналежності комісарів.

Більшість комісарів у минулому були міністрами в національних урядах та входили до національного чи європейського парламентів. Ураховуючи досвід нинішніх комісарів, розуміємо, що У. фон де Ляєн і СК зробили потужний акцент саме цифрових й інноваційних технологіях, що відображено в пріоритетах інституції [20]. Також комісари мають зв'язки з різними урядовцями та політиками цієї й попередньої каденцій. Наприклад, Ф. Тіммерманс, який є Першим віце-президентом Європейської зеленої угоди, працював ще в комісії Ж. Юнкера й вважався його правою рукою. Крім Ф. Тіммерманс, комісарами залишилися М. Вестагер (віце-президент відповідає за реалізацію проєкту «Європа цифрової епохи»), Й. Ган (комісар із питань бюджету та адміністрація), М. Габрієл (комісар із питань інновацій і молоді), В. Йоурова (віце-президент із питань цінностей та прозорості), М. Схінас (віце-президент із підтримки європейського способу життя), Ф. Хоган (комісар із питань торгівлі), М. Шефчович, (віце-президент із міжвідомчих відносин та прогнозування), Х. Боррелл, (віце-президент iз зовнішньої політики). Серед комісарів $\epsilon$ ті, що були парламентарями в минулому скликані: М. Габрієл (комісар із питань інновації і молоді), В. Домбровскіс (віце-президент відповідає за реалізацію економіка для людей), Д. Шуїця (віце-президент із питань демократії й демографії), 
Я. Войцеховський (комісар із питань сільського господарства), Е. Феррейра (комісар із питань згуртованості та реформ), А. Валеан (комісар із питань транспорту) [21]. Як бачимо, склад комісії У. фон де Ляєн не настільки оновлений, Свропейським Союзом управляють ті ж самі бюрократи, але на інших позиціях. Крім того, у комісії є навіть євроскептики, зокрема представник зі Словаччини М. Шефович, який, хоч і $є$ членом ЄНП, однак відкидає федералізацію ЄС та проти спільної податкової й міграційної політики [22]. Також євроскетичні погляди підтримує В. Йоурова [23]. Обидва представники мають зв'язки з Росією. Цікава ситуація з комісаром із питань енергетики К. Сімсон, чий батько був багаторічним радником мера Естонії Е. Савісаара, партію якого, за різними джерелами, фінансувала саме Росія [24].

В історії СС були випадки, коли комісари паралельно працювали в Європейській комісії й готувалися до національних виборів. Наприклад, президент ЄК Р. Проді агітував на італійських виборах, комісар А. Діамантопулу залишила Єврокомісію, щоб брати участь у грецьких виборах, а комісар Л. Мішель заявив, що піде у відпустку, щоб узяти участь у бельгійських виборах [25]. Знижує легітимність ЄК і ситуація 3 формуванням кандидатур на посаду президента Європейської комісії, як це було у випадку з У. фон Ляєн. Однак у СК працюють не лише комісари - в установі нараховується понад 32 тисячі співробітників [26], і всі вони прямо чи опосередковано впливають на кінцевий проєкт закону чи рішення.

Така кадрова політика та поглиблення інтеграції, а саме надання ЄК більших повноважень актуалізують проблему політизації інституцій $\mathrm{EC}$, у зв'язку з чим виникає питання, а чи впливають євроскептики на внутрішні процеси роботи СК. Дослідження, проведені співробітниками департаменту публічного адміністрування та соціології Ротердамського університету щодо політизації $Є К$ у питаннях преференцій соціального інвестування [27], і дослідження Х. Вільямс та С. Беван показали, що рівень євроскептицизму не впливає на динаміку прийняття рішень. Тобто, незважаючи на те, чи більш, чи менш проєвропейськими $є$ комісари, вони приймають таку саму кількість законопроєктів. Хоча рівень євроскептицизму зріс, порівняно 3 попереднім семестром, кількість прийнятих комісією односторонніх нормативно-правових актів суттєво не змінилася [28]. Однак немає відповіді чи в затверджених рішеннях прослідковуються євроскептичні ідеї.

Чи не найбільш євроскептичним органом вважають Свропейський парламент, оскільки він формується 3 політичних партій держав-членів. Якщо охарактеризувати парламент цього скликанням на чолі Д. Сас- 
солі, то він більш поляризований та менш однорідний. Політичні групи все менше сконцентровані на ідеології, а значно більше - на політичній приналежності партій. Політику євроскептиків у парламенті регулюють лідери політичних партій і груп, тому варто визначити, яку позицію представляють лідери цих партій та наскільки вона збігається із загальною політикою партії й групи. Найбільшою євроскептичною групою в європарламенті є ідентичність та демократія (далі - ІД), до яких приєдналася розформована після Брекзит група Європа свободи та демократії. А також до партії перейшли Справжні фіни й Данська народна партія з ЄКР. Головою партії є М. Занні, який був членом італійської менш євроскептичної партії Рух п'яти зірок, проте у 2018 р. перейшов до Ліги [29]. М. Занні-молодий політик i, найімовірніше, делегований лідерами групи представляти іiї на політичній арені. Засновницею та однією 3 найвпливовіших членів групи, безумовно, є лідерка французького Національного фронту М. Лє Пен. Саме вона тривалий час підтримувала дезінтеграційні процеси в ЄС, закликаючи французів до виходу 3 організації. Проте останнім часом помітні тенденції до послаблення жорсткої риторики, зокрема М. Лє Пен відмовилася від виходу із зони євро [30], а на початку 2020 р. погоджується на членство й хоче лише реформувати організацію [31]. Лідер італійської партії Ліга М. Сальвіні, навпаки, більше почав критикувати СС за бездіяльність на фоні пандемії. Проте його партія починає втрачати своїх прихильників [32]. Не можна поза увагою залишити лідера німецької Альтернативна для Німеччини Й. Мейтена, партія якого була більш проамериканською однак в останні роки риторика змістилася в бік жорсткої критики СС. Попри це, лідер партії Й. Мейтен не прихильник такої опозиції до СС [33]. Саме Італія, Франція та Німеччина отримали найбільше місць у Свропарламенті. Інші держави, такі як Чехія, Фінляндія, Данія, Естонія, Бельгія, Австрія, Нідерланди, отримали 1-3 місця відповідно. Група Ідентичність та Демократія відносно нова група, яка сформована 3 нових популістів і євроскептиків. Досить часто партії ІД пов'язують із різними зацікавленим групами. Зокрема, партія «Нідерландів за свободу», за різними джерелами, фінансується лобістами зі США [34], Партія свободи Австрії виступає проти посилення санкцій i за розширення співпраці з Росією [35]. Також не варто відкидати тісне співробітництво між Національним фронтом М. Лє Пен та Росією, зокрема 2015 р. партія отримала позику від російського банку [36]. Найвище серед євроскептичних груп електоральне представництво ІД в європарламенті сприяє тому, що партії перетворюються на мішені лобіювання зацікавлених держав із боку як $\mathrm{CC}$, так і третіх країн.

Група Європейських консерваторів та реформістів була найбільшою 
євроскептичною групою в попередньому парламенті. Після виходу британської Консервативної партії як провідної та інших партій до Європейських консерваторів i реформістів приєдналися більш популістичні партії іспанський Вокс, Сімейна партія Німеччини, Грецьке рішення та голландський Форум за демократію. Через це група змінила свою ідеологію й політичне спрямування від поміркованого євроскептицизму до більш радикального. Зокрема, вихід із СС підтримують партії Грецьке рішення, чеська Громадська демократична партія та голландський Форум за демократію. Також жорстку позицію щодо функціонування єврозони та подальшого співробітництва мають словацька Свобода і солідарність, Болгарський національний рух. Зараз групу очолює італієць Р. Фітто спільно з поляком Р. Лугутко. Диктує політику групи польська Право та справедливість, оскільки отримала близько половини місць із 52 можливих. Також до групи входять ще дві польські партії Об'єднана Польща та Угода. Лідируючі позиції займають представники партій Брати Італії та Вокс. Головною партією групи була Консервативна партія Британії, однак після Брекзиту, група втратила свої позиції в ЄП.

Найменшою євроскептичною групою $є$ «Європейські об'єднані ліві» - Північно зелені ліві, що представляють м'який євроскептицизм. До групи входять комуністичні партії та ліві. Тривалий час саме ця група вважалася проросійською. До парламентської групи цього скликання ввійшли також представники політичного руху Тепер Народ та партії Лівий блок (Португалія), Подемос (Португалія), Ліва партія (Швеція), Лівий союз (Фінляндія), Червоно-зелений альянс Данії і Нескорена Франція, що заснований у 2018 р., проте не зареєстровані як партія ЄC [37]. Також сюди входять п’ять партій, які не є членами жодного європейського альянсу. У групі наявні партії, налаштовані як більш жорстко, так і помірковано. Зокрема, вихід з організації підтримують партії Португалії, Данії та Чехії. Поступово партії групи втрачають свою підтримку серед населення, а група перетворюється на об'єднаний блок партій, погляди яких не сумісні з іншими групами.

Такі внутрішні партійні процеси дещо вплинули на рівень євроскептицизму в СП. Відповідно до досліджень, проведених А. Ріполь, визначено, що рівень євроскептицизму в Свропарламенті 2020 р. становить $31 \%$, а кількість євроскептиків у 2014-2019 рр. - 27\%. Проте ситуація не така однозначна. Хоча свою підтримку втратили проєвропейські Європейська народна партія та Прогресивний альянс соціалістів i демократів, однак підтримка іншої проєвропейської партії Оновлена 
Європа, навпаки, зросла. Також більше громадян підтримали Зелених. Серед євроскептичних груп свою підтримку втратили Європейські консерватори й реформісти та Ліво-зелені Півночі, коли Ідентичність та демократія виграли голоси [38].

Статистика свідчить, що кількість євроскептиків у парламенті зросла, але вона не показує, як змінилося якісне співвідношення євроскептичних груп. Найбільша євроскептична група Ідентичність та демократія не підтримує вихід з організації, проте є дві умови, які відстоюють національні партії: реформування зони євро й боротьба 3 нелегальною міграцією. Хоча Ідентичність та демократія не $\epsilon$ прихильниками жорсткої опозиції, проте саме з їхньої партії лунає чи не найбільше критики до ЄС. У той час як інша права група Європейських консерваторів та реформістів - прихильники жорсткого євроскептицизму - відкидають подальшу інтеграцію як прихильники виходу з ЄС. Також більш радикально налаштовані Ліві. Зокрема, у новому парламенті зафіксовано п'ять партій жорсткого євроскептицизму: голландський Форум за демократію, чеська Свобода та пряма демократія, словацька партія Котлеба й Комуністична партія, а також Золота світанок із Греції, серед яких є представники всіх трьох опозиційних груп. Як бачимо, зміщення сил відбулося від лівих до правих євроскептиків, так само - від жорсткого євроскептицизму до м'якого. Це свідчить про те, що євроскептики не виступають однією силою ні в європейському парламенті, ні в Свропі. Можна припустити, що пік жорсткої опозиції до $\mathrm{CC}$ знижується, прихильники виходу з організації чи призупинення певної політики втрачають свою підтримку. Результати останніх виборів показують, що громадяни держав-членів, особливо регіону ЦСЄ, і політична еліта потребують якісно нового союзу, нової стратегії співробітництва. Під час голосування важливу роль відіграє саме консенсусне рішення. Проте за умови його відсутності євроскептичні партії несуттєво можуть вплинути на результат голосування, оскільки саме проєвропейські групи Європейська народна партія, Прогресивний альянс соціалістів і демократів та Альянс лібералів і демократів за Європу формують велику проєвропейську коаліцію [39]. Свроскептики можуть реалізувати свою діяльність через парламентські комітети, адже саме вони вносять поправки пропозиції комісії та зауваження Ради СС. Таку політику також можна інтерпретувати як лобізм.

Ще одним осередком євроскептицизму є Рада $\mathrm{CC}$, яка паралельно 3 парламентом редагує й затверджує законодавство СС. Міністри Ради ЄC намагаються регулювати вплив законодавчої ініціативи ЄК на 
національне законодавство, адже саме профільні міністерства державчленів вносять поправки до законопроєктів СК. Прослідкувати прояви євроскептицизму в Раді ЄС досить складно та певною мірою навіть неможливо, оскільки складно визначити яка чергова поправка одного 3 міністрів 27 держав-членів суперечить європейській інтеграції чи просто інтересами держави. Крім того, процес призначення уряду або формування коаліції дуже динамічний. Звільнення та призначення нового міністра, закінчення каденції уряду чи взагалі відправлення уряду у відставку - не такі вже рідкісні процеси в державах Свропи.

Хоча кількість опозиційних партій і прихильників цієї ідеології зростає, представництво євроскептиків у національних урядах не таке вже велике. Найбільш євроскептичні уряди мають Угорщина, Польща, Італія, Австрія [40]. В Угорщині урядові партії відкрито не називають себе євроскептичними й входять у Європейську народну партію. Партія, яка займає головні міністерські крісла, - Фідес (прем'єр-міністр, міністр фінансів, міністр закордонних справ і торгівлі, міністр юстиції та міністри офісу прем'єр-міністра). Християнсько-демократична народна партія, яка відхилила прийняття Європейської конституції, отримала лише два міністерства. Безпартійні представники одержали інші вакантні міністерства, серед яких - Міністерство внутрішніх справ [41]. В Італії міністерства розділені між проєвропейською Демократичною партією та євроскептичною партією - Рухом п'яти зірок. Зокрема, євроскептична партія отримала Міністерство зовнішніх справ та міжнародного співробітництва, Міністерство економічного розвитку, Міністерство юстиції, Міністерство праці та соціальної політики й Міністерство освіти, університетів та досліджень [42]. В Австрії ситуація з формуванням уряду така сама, як і в Італії, оскільки він складається 3 проєвропейської Австрійської народної партії та 3 євроскептичної Партії свободи. Зокрема, остання отримала керівництво над такими міністерствами, як Міністерство транспорту, інновацій i технологій, Міністерство оборони i спорту, Міністерство праці, соціальної політики і захисту споживачів та Міністерство внутрішніх справ [43]. У Польщі після виборів улітку 2020 р. реформування уряду й, відповідно, скорочення кількості міністерських крісел ситуацію суттєво не змінили. До уряду приєднався Я. Качинський від партї̈ Право та справедливість на посаду віцепрем’єр-міністра. Партія фактично очолює євроскептичну групу Свропейських консерваторів і реформістів [44]. Дискусійним залишається питання впливу міністрів-євроскептиків на курс держави і їі політику в організації.

Дослідження, проведені П. Груйсена та К. Кромбеза, показують 
незначний вплив міністрів-євроскептиків на процес прийняття рішення. Учені вивчали, чому певні міністри не підтримують те чи інше рішення, як часто голосують проти і що цьому передує. Одним із визначників у цьому досліджені був євроскептицизм. Результати дослідження демонструють, що загальна опозиція до $Є С$ не $\epsilon$ визначальним фактором у процесі голосування чи прийняття рішення. Відповідно до даних, зв'язок між євроскептицизмом та інституцією менше 10 \%. Тобто це означає, що ні євроскептицизм, ні приналежність міністра до такого курсу не впливають на прийняття чи неприйняття рішення.

Якщо розглянути внутрішній процес прийняття рішення в Раді $\mathrm{CC}$, то треба зауважити, що не лише міністри беруть участь у формуванні політики інституції. Значну роботу також виконують Комітет із тимчасових представників (COREPER) та робочі групи. Ураховуючи високий рівень поляризації інтересів і сторін, органи намагаються максимально досягати консенсусного рішення й більше зорієнтовані на стабільну роботу інституції з урахуванням інтересів усіх держав-членів, аніж до дестабілізації внутрішньої політики [45]. Крім того, критика чи відмова від рішення, яке передбачає посилення інтеграційного процесу, не означає підтримку чи прихильність до євроскептицизму. Причина цього передусім економічна, соціальна чи політична неготовність національного уряду до імплементації таких ідей. 3 усіх інституцій $Є С$ найменше та найскладніше євроскептицизм проявляється саме в Раді СС через низький рівень політичної заангажованості.

Євроскептицизм - це масштабне явище, ознаки якого можна простежити не лише в головних політичних інституціях СС. Свої інтереси зацікавлені групи можуть просувати через різні консультативні органи, зокрема Європейський економіко-соціальний комітет, який представляє громадянське суспільство, профспілки, групи інтересів і комітет регіонів, що формує політичні групи, котрі представляють їхні інтереси. Також треба врахувати роль децентралізованих агентств: агентства спільноти, агентства у сфері спільної зовнішньої політики та політики безпеки, агентства у сфері співробітництва поліцейських і судових органів у кримінально-правовій сфері, виконавчі агентства. Тобто СС це не лише декілька інституцій і представники держав-членів, СС - це потужна й величезна організація із сотнями тисяч співробітників, які формують політику організації.

Проаналізувавши прояви євроскептицизму в інституціях СС, можемо зробити певні висновки. Зокрема, функції та завдання інституцій $\mathrm{CC}$ закріплені в договорах, проте на неформальному рівні кожна інституція 
відповідальна за певний процес в організації. Інтенсивність та швидкість інтеграції залежать від Європейської ради і Європейського парламенту. I якщо більшість лідерів держав чи парламентів не готові до поглиблення співробітництва, то посилення кооперації не відбудеться. Тому рівень і прояви євроскептицизму саме в цих інституціях є надважливим. В інших інституціях - Свропейській комісії та Раді СС, які не несуть політичної відповідальності за реалізацію рішення, - рівень опозиції до ЄС не настільки важливий, оскільки вони зосереджені на реалізації технічних моментів - прийнятті та імплементації законів. Тобто євроскептицизм особливу силу має саме в політичних органах $\mathrm{EC.}$

Також прояви євроскептицизму в інституціях залежать від впливу національного уряду та парламенту. Якщо позиції євроскептиків потужно представлені в державі, то ці ж урядовці можуть диктувати політику і в самій організації. Потрібно зауважити, що ідеї євроскептицизму переважно поширюють не політичні партії чи групи, а політичні лідери та популісти, які критикують ЄС. Крім того, ці ж представники мають зв'язки з Росією. Лідери держав-членів, політичних партій, депутати Свропарламенту критикують $€ C$ за бездіяльність, але саме вони є тим механізмом, який регулює цей процес бездіяльності. Політики держав-членів відокремлюють ЄС від національних урядів, забуваючи, що уряд $\mathrm{CC}$ сформований із національних представників.

\section{4. ВИСНОВКИ ТА ПЕРСПЕКТИВИ ПОДАЛЬШИХ ДОСЛІЖЖНЬ}

Охарактеризувавши та проаналізувавши прояви євроскептицизму в інституціях $\mathrm{CC}$, визначивши приналежність до євроскептицизму лідерів держав чи урядів, європейських комісарів, депутатів Європейського парламенту, а також коротко окресливши й інші можливі шляхи зростання євроскептицизму в інституціях $\mathrm{CC}$, зазначимо, що опозиція до $\mathrm{EC}$ не $\epsilon$ критичною загрозою роботі європейських інституцій. Безумовно, певний рівень критики та зауважень до роботи $Є С$ є серед працівників органів $€ C$, проте він не загрожує інтеграції. Значно більша проблема - відсутність політичної волі лідерів та неготовність держав-членів щодо поглиблення співпраці. Проте вирішення цього питання потребує значно більше часу й зусиль, над чим активно працюють у ЄС. Адже ми бачимо позитивні тенденції в роботі інституцій організації як у політиці розширення, так і в урегулюванні внутрішніх суперечностей. У перспективі треба проаналізувати вплив лобістів на роботу інституцій СС крізь призму євроскептицизму. 


\section{СПИСОК ВИКОРИСТАНИХ ДЖЕРЕЛ}

1. Treaty of Lisbon (2007). URL: https://eur-lex.europa.eu/LexUriServ/LexUriServ.do?uri=OJ:C:2007:306:FULL:EN:PDF

2. The EU decision-making process. URL: https://www.nhsconfed.org/-/media/Confederation/Files/Publications/Documents/The-EU-decision-making-process.pdf

3. Leconte C. Understanding Euroscepticism, 2010. URL: https://books.google. com.ua/books?id=RQMdBQAAQBAJ\&printsec=frontcover \&hl=uk\&source=gbs $\mathrm{atb} \# \mathrm{v}=$ onepage $\& \mathrm{q} \& \mathrm{f}=$ false

4. Mude, C. (2019). European governments are fuelling Euroscepticism. The Guardian. URL: https:/www.theguardian.com/commentisfree/2019/jul/15/european-council-fueleuroscepticism-governments-eu

5. Mudde, C. ( 2019). European governments are fuelling Euroscepticism. The Guardian. URL: https://www.theguardian.com/commentisfree/2019/jul/15/european-council-fuel-euroscepticism-governments-eu

6. Williams, C., Bevan, S. (2019). The effect of public attitudes toward the EU on the European Commission's policy activity. European Politics and Policy or the London School of Economics. URL: https://blogs.1se.ac.uk/europpblog/2019/08/23/the-effect-of-public-attitudes-toward-the-eu-on-the-european-commissions-policy-activity/

7. Members of the European Council. European Council. Council of the European Union. URL: https://www.consilium.europa.eu/en/european-council/members/

8. Anti-corruption digest Bulgaria. Critics slam Bulgarian corruption probe. Council of Europe (2019). URL: https:/www.coe.int/en/web/corruption/anti-corruption-digest/ bulgaria?fbclid=IwAR02Im1pH93kLqqmQKngQ536GtnrQsjYtGtbM2SYW73u11AAMPJ TZPmBNwI

9. European Commission confirms Czech Prime Minister Andrej Babiš has conflict of interest. Transparency International (2019). URL: https://www.transparency.org/en/press/ european-commission-confirms-czech-prime-minister-andrej-babish-has-conflic?fbclid=Iw AR3WF2QSXDL4rcYJgJcU0pJdcztI_ASrZGWMXW4URM5r2tVeBQ0WoTA6DxA\#

10. Bulgaria, Czech Republic calls for EU reforms on migrants. The Associated Press (2018). URL: https://apnews.com/eb2c88ce2d834e98987e6dc8f473194d/Bulgaria,-CzechRepublic-calls-for-EU-reforms-on-migrants?fbclid=IwAR3o_fouzNnRy1vn3L-4-ASsXBIntCAzVgWJnEzll19JpNrQUgJKGPggBAE

11. Stone, J. (2019). Denmark gets new left-wing government with plans to increase welfare spending and scrap anti-immigration measures. Independent. URL: https://www. independent.co.uk/news/world/europe/denmark-new-government-left-mette-frederiksenwelfare-spending-anti-immigration-a8975096.html

12. Hall, B., Atkins, R. (2019). Sebastian Kurz: saviour of Europe's mainstream or friend of the far-right? The Financial Times.. URL: https://www.ft.com/content/9396664c044d-11e9-9d01-cd4d49afbbe3

13. Kingsley, P. (2018). Safe in Hungary, Viktor Orban Pushes His Message Across Europe. The New York Times. URL: https:/www.nytimes.com/2018/06/04/world/europe/ viktor-orban-media-slovenia.html

14. Bank Records Link President of Cyprus to 'Troika Laundromat'. OCCRP (2019). URL: https://www.occrp.org/en/troikalaundromat/bank-records-link-president-of-cyprus- 
to-troika-laundromat

15. Ratas peab koalitsiooni EKRE-ga võimatuks. ERR (2018). URL: https://www.err. ee/879109/ratas-peab-koalitsiooni-ekre-ga-voimatuks

16. Barigazzi, J. (2020). Conte's gamble. The Italian prime minister is caught between frugal EU leaders and a frightened, furious public. POLITICO. URL: https://www.politico. eu/article/giuseppe-conte-gamble-coronavirus-european-union-leaders/

17. Hyndle-Hussein, J. (2019). Nausėda, Lithuania's new president. Ośrodek Studiów Wschodnich. URL: https://www.osw.waw.pl/en/publikacje/analyses/2019-05-28/nausedalithuanias-new-president

18. Baerg, N., Hallerberg, M. (2016). Explaining Instability in the Stability and Growth Pact: The Contribution of Member State Power and Euroskepticism to the Euro Crisis. URL: http://repository.essex.ac.uk/17897/1/Baerg_Hallerberg.pdf

19. Verga, C. (2014). Aspect of Romania's Representation at the European Council. Procedia - Social and Behavioral Sciences. URL: https://www.sciencedirect.com/science/ article/pii/S1877042814050435

20. Leyen, U. (2019). A Union that strives for more. My agenda for Europe European Commission. URL: https://ec.europa.eu/info/sites/info/files/political-guidelines-next-commission_en_0.pdf

21. Meet the commissioners. All you need to know about Ursula von der Leyen's team. POLITICO (2019). URL: https://www.politico.eu/article/meet-the-commissioners-president-ursula-von-der-leyen-team-european-commission-members/?fbclid=IwAR3Oph0qUh zws7L1D3hN3cUKnM1U4cZ2SikJfWPhWhyW95B_pBi3cIZm4do

22. King, E. (2018). Maroš Šefčovič to run for Commission top job. POLITICO. URL: https://www.politico.eu/article/maros-sefcovic-commission-social-democrats-to-run-forcommission-top-job/

23. Gardner, A. (2016).Verra Jourová: Feisty commissioner. Profile of the European commissioner for justice. POLITICO. URL: https://www.politico.eu/article/vera-jourovafeisty-commissioner/

24. Kox, T. (2010). Вокруг Сависаара разгорелся скандал. Postimees. URL: https:// rus.postimees.ee/358681/vokrug-savisaara-razgorelsya-skandal

25. Commissioner Louis Michel to stand in the Belgian parliamentary elections. European Commission (2007). URL: https://ec.europa.eu/commission/presscorner/detail/en/ IP 07344

26. European civil service. European Commission. URL: https://ec.europa.eu/info/ about-european-commission/organisational-structure/commission-staff_en

27. Veer, R., Haverland, M. (2007). Bread and butter or bread and circuses? Politicisation and the European Commission in the European Semester. SAGE. URL: https://journals. sagepub.com/doi/pdf/10.1177/1465116518769753

28. Williams, C., Bevan, S. (2019). The effect of public attitudes toward the EU on the European Commission's policy activity. European Politics and Policy or the London School of Economics. URL: https://blogs.lse.ac.uk/europpblog/2019/08/23/the-effect-of-public-attitudes-toward-the-eu-on-the-european-commissions-policy-activity/

29. Suyak, F. (2019). Italian MEP Marco Zanni of far-right League party on Conflict Zone. Deutsche Welle. URL: https://www.dw.com/en/italian-mep-marco-zanni-of-far-rightleague-party-on-conflict-zone/a-47462784 
30. Sapin, C. (2019). Le Rassemblement national abandonne définitivement la sortie de l'euro. Lefigaro. URL: https://www.lefigaro.fr/politique/2019/01/16/01002-20190116ARTFIG00326-le-rn-abandonne-la-sortie-de-l-euro.php

31. Marine Le Pen: EU has more to lose on Brexit, but I don't want Frexit. Euronews (2020). URL: https://www.euronews.com/2020/02/06/marine-le-pen-eu-has-more-to-loseon-brexit-but-i-don-t-want-frexit

32. Vergine, S. (2020). Coronavirus: Are Italians losing faith in the EU? BBC. URL: https:/www.bbc.com/news/world-europe-52666870

33. Germany's AfD: How right-wing is nationalist Alternative for Germany? $B B C$. (2020). URL: https:/www.bbc.com/news/world-europe-37274201

34. Deutsch, A. Hosenball, M. (2012). Exclusive: U.S. groups helped fund Dutch anti-Islam politician Wilders. Reuters. URL: https://www.reuters.com/article/us-dutchwilders-us/exclusive-u-s-groups-helped-fund-dutch-anti-islam-politician-wilders-idUSBRE8890Q820120910

35. Austrian Far-Right Party Signs Cooperation Pact With United Russia. Radio Liberty (2016). URL: https:/www.rferl.org/a/russia-austria-freedom-party-pact-putins-party/28185013.html

36. Europe is trying to keep Russia from influencing its elections. The Economist (2017). URL: https://www.economist.com/europe/2017/04/15/europe-is-trying-to-keeprussia-from-influencing-its-elections

37. Now the People! - Brussels declaration. Now the People (2018). URL: https://nowthepeople.eu/now-the-people-brussels-declaration/

38. Ripoll, A. (2019). The new European Parliament: more eurosceptic? URL: https:// ukandeu.ac.uk/the-new-european-parliament-more-eurosceptic/

39. Servent, A. (2019).The European Parliament after the 2019 Elections: Testing the Boundaries of the 'Cordon Sanitaire'. Journal of Contemporary European Research. URL: https:/www.researchgate.net/publication/337973203_The_European_Parliament_after_the_2019_Elections_Testing_the_Boundaries_of_th National parliamentary control and voting in the Council of the EuropeanUnione_Cordon_Sanitaire

40. Barnes, J. (2018). Euroscepticism MAPPED: Five countries threatening to ROCK the EU. Daily Express. URL: https://www.express.co.uk/news/world/941976/EU-newsfive-eurosceptic-countries-threaten-European-Union

41. Members of the Government. The Government of Hungary (2020). URL: https:// www.kormany.hu/en/members-of-the-government

42. Ministri e Sottosegretari. Governo Italiano Presidenza del Consiglio dei Ministri (2020). URL: http://www.governo.it/it/il-governo

43. Federal Government. Federal Chancellery Republic of Austria (2020). URL: https:// www.bundeskanzleramt.gv.at/en/federal-chancellery/the-austrian-federal-government.html

44. Charlish, A., Plucinska, J. (2020). Poland's government heads further to the right in new lineup. Reuters. URL: https:/www.reuters.com/article/us-poland-politics/polandsgovernment-heads-further-to-the-right-in-new-lineup-idUSKBN26L247

45. Leconte, C. (2010). Understanding Euroscepticism. URL: https://books.google. com.ua/books?id=RQMdBQAAQBAJ\&printsec $=$ frontcover $\&$ hl $=$ uk \& source $=\mathrm{gbs}$ 
$\mathrm{atb} \# \mathrm{v}=$ onepage $\& \mathrm{q} \& \mathrm{f}=$ false $\mathrm{s} .15$

\section{THE EUROSCEPTICISM INFLUENCE ON THE EU INSTITUTIONS' FUNCTION}

This article examined the indications of Euroscepticism in the EU institution. In particular, it analysed elements of opposition to the EU in the European Council, the European Commission, the European Parliament and the Council of the European Union, and in other EU subsidiary bodies. I paid considerable attention to studying the political views of the Heads of State and Government of the European Council. The study found leaders of mostly Central and Eastern European countries have ties to Russia and criticise the organisation's policies that weaken integration, although are members pro-European parties. Much attention has been drawn to the ideology of political parties and groups that are members of the European Parliament. Looking at the research, the number of Eurosceptics in the European Parliament has not decreased, but there is no strengthening of communication and cooperation between them. This means the level of Euroscepticism in parliament declined. Besides, it described the political views of the commissioners and their commitment to the ideas of Euroscepticism. As a result, the European Commission remains the most pro-European institution. The article also considered Euroscepticism in the EU Council. Hence, Member States have doubts about the EU policies that slow down cooperation. However, it is difficult to argue about the rise of Euroscepticism in the EU institutions and its negative impact on strengthening cooperation. European integration is a rather complex process, influenced not so much by Euroscepticism as by the economic situation, the unification of legislation, and international relations. Euroscepticism in the institutions is not a threat to European integration, but only as a factor which slows down cooperation and promotes adaptation states and their citizens.

Key words: Euroscepticism; European Council; European Parliament; European Commission; Council of the EU.

Матеріал надійшов до редакиії 08.10.2020 p. 